\title{
PENERAPAN KONSEP ARSITEKTUR PRAGMATIK PADA BANGUNAN BANDAR UDARA KERTAJATI
}

\author{
${ }^{1}$ Kahfi Saydani Zeni, ${ }^{2}$ Lutfi Prayogi \\ 1-2Universitas Muhammadiyah Jakarta, Jakarta, Indonesia \\ Zen.kahfi@gmail.com ${ }^{1}$
}

\author{
Informasi Naskah \\ Diterima: 31/05/2020; Disetujui terbit: 29/12/2020; Diterbitkan: 29/12/2020; \\ http://journal.uib.ac.id/index.php/iad
}

\begin{abstract}
ABSTRAK
Bandar udara adalah area tertentu yang berada di daratan atau perairan (termasuk bangunan, instalasi dan peralatan) yang diperuntukkan baik secara keseluruhan atau sebagian terutama untuk kedatangan, keberangkatan dan pergerakan pesawat. Tingkat aktivitas pada setiap bagian bangunan tidak hanya melibatkan manusia maupun kendaraan umum (mobil dan bus) tetapi juga barang-barang yang dibawa oleh pengguna hingga ruang gerak pesawat pada landasan bandar udara. Karena beragam aktivitas rumit terjadi di dalamnya, maka bandara menjadi salah satu bangunan yang tingkat kompleksitasnya tinggi, sehingga harus lebih diprioritaskan pada aspek fungsional dalam desain bangunannya. Namun pada kenyataannya, di Indonesia aspek bentuk dan keindahan (estetika) menjadi suatu prioritas dalam mendesain suatu bangunan. Sehingga aspek fungsional yang menjadi faktor penting sering tidak diperhatikan terutama untuk bangunan bandar udara. Berdasarkan latar belakang tersebut maka perlu penerapan arsitektur pragmatik sehingga aspek fungsional seperti keselamatan, keamanan, pelayanan dan kenyamanan pengguna dapat terpenuhi tanpa perlu mempertimbangkan estetika dari bentuk massa bangunan itu sendiri. Penelitan ini bertujuan untuk memahami penerapan konsep pragmatik pada arsitektur bandar udara dan penerapan elemen-elemen serta sirkulasi yang ada di dalamnya. Metode dalam penelitian ini menggunakan prinsip arsitektur pragmatik menurut Geoffrey Broadbent. Penerapan arsitektur pragmatik menghasilkan desain suatu bangunan yang sederhana dan fungsional terhadap seluruh aktivitas pengguna dari segi aspek pelayanan, kemudahan (kenyamanan), keamanan, keselamatan hingga sirkulasi pengguna di dalamnya.
\end{abstract}

Kata Kunci: arsitektur, konsep pragmatik, bandar udara

\begin{abstract}
Airport is a certain area that is on land or water (including buildings, installations and equipments) that is intended for the whole area or a large portion to be visited, allocated and aircraft movements. The level of activity in each part of the building does not only involve humans or public vehicles (cars and buses), but also goods carried by users to the aircraft's space on the airport runway. Because a variety of complicated activities occur here, the airport is one of the buildings with a high level of complexity, so it must be prioritized in the aspect of functionality in building design. However, in Indonesia aspects of form and aesthetics are a priority in designing a building. Specially designed for airport buildings. Based on this background, it is necessary to apply pragmatic architecture so that functional aspects such as safety, security, and user comfort can be fulfilled without the need to consider the aesthetics of the mass form of the building itself. This research discusses the application of pragmatic concepts in airport architecture and the application of elements and circulation in implementation. The method in this study uses the pragmatic principle according to Geoffrey Broadbent. The application of pragmatic architecture results in a simple and functional building design for all user activities in terms of service, convenience, security, safety to user's circulation in the building.
\end{abstract}

Keywords: architecture, pragmatic concept, airport 


\section{Pendahuluan}

Bandar Udara merupakan tempat atau fasilitas tersibuk yang menjadi pusat aktivitas manusia selama 24 jam dan aktif dalam menggunakan transportasi udara. Indonesia masuk dalam salah satu bandar udara tersibuk di Dunia peringkat ke 18 pada tahun 2019 dengan total 66,9 juta penumpang (Fista, 2020). Beragam kompleksitas yang terjadi di dalamnya, tentu melibatkan berbagai aspek penting dalam mendesain sebuah bandar udara. Menteri Perhubungan Republik Indonesia tahun 2014-2016, Ignasius Jonan mengatakan bahwa beberapa hal penting yang harusnya menjadi perhatian utama pada desain bandara antara lain keselamatan (safety), keamanan (security), pelayanan (service), dan kenyamanan. Jika desain sebuah bandara mengalahkan fungsi, maka biaya perawatan dipastikan akan besar (Imaji, 2019). Sayangnya beberapa bandara di Indonesia masih memprioritaskan akan desain bangunan dibanding dengan fungsi bangunan itu sendiri. Hal ini terbukti dari keluhan beberapa pengguna bandar udara di Indonesia. Kepala Bappeda Kalsel, Nurul Fajar Desira dan beberapa penumpang bandara mengatakan bahwa jarak dari area parkir menuju ke ruang tunggu keberangkatan jaraknya terlalu jauh, sehingga memakan waktu lebih banyak untuk check in hingga ke ruang tunggu. Keluhan yang sama disampaikan oleh penumpang yang mengakses jalan menuju bandara menggunakan kendaraan, akses jalan terkesan tidak memudahkan penumpang dan harus memutari jalan yang lebih jauh (Sutrisno, 2020).

Di sinilah seharusnya arsitektur berperan. Bagaimana suatu bandar udara dapat memprioritaskan kemudahan pengguna dibandingkan desain bandara itu sendiri. Dalam dunia arsitektur, terdapat suatu konsep yang memprioritaskan aspek fungsional suatu bangunan dibandingkan desainnya, yaitu Arsitektur Pragmatik. Konsep Arsitektur Pragmatik sebenarnya sudah menjadi hal mendasar dalam setiap mendesain suatu bangunan. Pendekatan pragmatik adalah penyelesaian satu atau beberapa masalah tertentu yang nyata dan terukur, misalnya iklim, keterbatasan lahan, dana, waktu pembangunan, akses menuju bangunan tersebut, dan/atau konstruksi spesifik. Dimana konsep ini sudah diterapkan di beberapa bandara Indonesia. Hal ini penting untuk diteliti, karena konsep arsitektur pragmatik yang diterapkan pada bandar udara ini dapat menghasilkan suatu bangunan yang fungsional terhadap seluruh aktivitas pengguna dari segi aspek pelayanan, kemudahan (kenyamanan), keamanan, keselamatan hingga sirkulasi pengguna di dalamnya

\section{Kajian Pustaka}

Penggunaan konsep pragmatik pada sebuah bandara, sebenarnya sudah sering diterapkan oleh para perancangnya, hal ini dikarenakan bandara adalah bangunan yang lebih harus memperhatikan fungsinya dalam mendesain. Agar lebih paham mengenai pengertian arsitektur kontemporer, maka beberapa definisinya antara lain :

\section{Kajian Arsitektur Pragmatik}

Pragmatik merupakan kajian bahasa dalam komunikasi yang berusaha memahami makna dalam kaitannya dengan situasi tutur (P. Ari Subagyo, 2010). Dalam pragmatik, latar belakang pengetahuan apa pun yang diasumsikan dimiliki bersama oleh penutur maupun pendengar, dan membantu pendengar menafsirkan apa yang dimaksudkan oleh penutur. Menurut Leech pragmatik meneliti maksud ujaran (yaitu untuk apa ujaran itu dilakukan) dengan cara menanyakan apa yang seseorang maksudkan dengan suatu tindak tutur; dan 
mengaitkan makna dengan siapa berbicara kepada siapa, di mana, bilamana, dan bagaimana (Sari, 2014). Dicatat dari referensi jurnal ilmiah bahwa Pendekatan pragmatik dalam hal arsitektur yaitu mempelajari suatu bangunan dengan melihat dalam ungkapan bentuk dan makna yang diteliti berdasarkan fungsi (yunianti, 2015). Tidak hanya bentuk dan makna, dalam jurnal milik Chairil, Amiuza, \& Ridjal, Pragmatik merupakan salah satu dari tiga unsur semiotika dalam membaca tata bahasa arsitektural. ketiga unsur tersebut adalah:

1. Sintaktik: mempelajari hubungan antara tanda-tanda tanpa melihat kenyataannya (dimanfaatkan oleh ilmu matematika dan logika)

2. Semantik: menyelidiki hubungan antara tanda-tanda dengan kenyataannya, hubungan antara tanda-tanda dengan designatun/significatum sekaligus dengan denotatumnya (dijelaskan lebih terperinci pada segitiga semantiknya Charles Morris)

3. Pragmatik: menyuguhkan hubungan antara tanda-tanda dengan para pemakainya, sehingga berisikan seluruh faktor psikologis dan sosiologis yang sekaligus berperan serta sebagai tujuan dan sasaran. Menurut Charles Morris simbol berperan ganda (Chairil, Amiuza, \& Ridjal, 2015).

\section{Aspek Arsitektur Pragmatik}

Aspek ini menguraikan dampak suatu bangunan terhadap perilaku pengguna bangunan yang dikaitkan dengan bahasa. Aspek dalam Arsitektur meliputi;

1. Bentuk fisik Bangunan.

Bentuk arsitektur pragmatik dalam hal fisik bangunan lebih mengutamakan makna fungsi daripada estetika. Elemen dekoratif yang digunakan pada bangunan pada pendekatan pragmatik, tidak hanya menjadi fungsi estetis, tetapi menjadi unsur fungsional (M. Pinem, 2016). Bentuk fisik bangunan yang diperhitungkan dalam arsitektur pragmatik adalah; ukuran, proporsi, jarak antar bagian, bahan, warna, dan sebagainya. Sebagai suatu sistem hal hal fisik tersebut dapat diinterpretasikan (mempunyai arti dan nilai) dan memancing reaksi tertentu dalam sebuah bangunan berdasarkan bahasa yang dihasilkan (T, C., Dariwu, \& Rengkung, 2012)

\section{Contoh Bangunan dengan Arsitektur Pragmatik}

Contoh lain bangunan yang mengambil pendekatan pragmatik pada konsepnya adalah bangunan suku eskimo. Bangunan tempat tinggal di wilayah tersebut memanfaatkan bahan pembentuk bangunan sebagai penanda tempat tinggal, dan juga sebagai penyesuaian terhadap iklim (Manaroinsong K. E., 2017). Seperti yang dijelaskan oleh gambar 1.

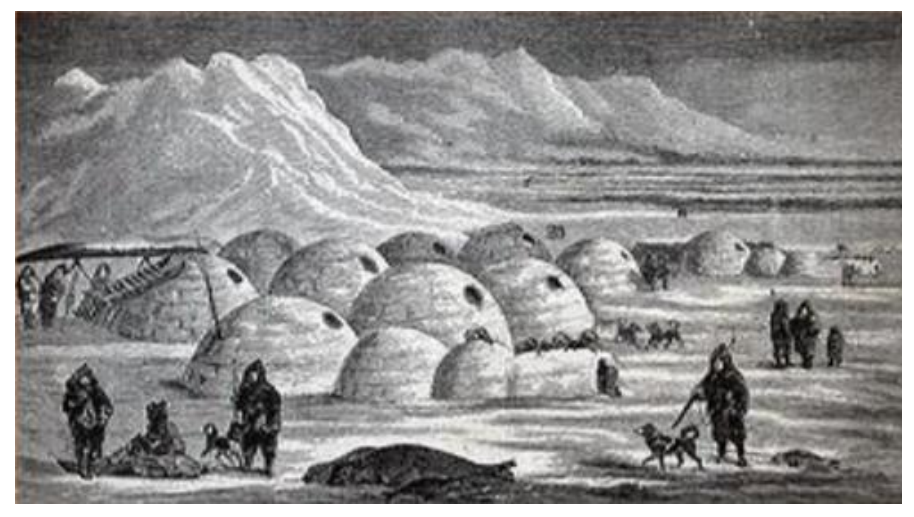

Gambar 1. Pemanfaatan alam sekitar sebagai bahan pembentuk rumah suku eskimo, dan faktor 
iklim mempengaruhi arsitektural

Sumber : Keren E. Manaroinsong, 2017

\section{Metode Penelitian}

Jenis penelitian yang digunakan adalah deskriptif-kualitatif. Deskriptif kualitatif merupakan suatu teknik yang menggambarkan dan menginterpretasikan arti data-data yang telah terkumpul dengan memberikan perhatian dan mendokumentasikan sebanyak mungkin aspek situasi yang diteliti pada saat itu sehingga memperoleh gambaran secara umum dan menyeluruh tentang keadaan sebenarnya. Tujuan penelitian kualitatif ini dikarenakan pemahaman dalam penerapan unsur pragmatik pada bangunan arsitektur bandara dapat disajikan dengan penuturan deskriptif yang subur dan terperinci. Cara Pengumpulan Data sebagai berikut :

1. Berkunjung langsung ke Bandara Kertajati dan mengambil informasi dari bahan pembentuk bangunan, signage yang tedapat di dalam maupun luar bangunan, elemen arsitektural yang berdasarkan pada warna, tanda, dan bentuk bangunan, serta alur keberangkatan dan ketibaan dengan cara memfoto dan mensketsa.

2. Mencari data yang belum di dapat pada bangunan Bandara Kertajati, dan Kulonprogo pada saat survey langsung seperti denah terminal, alur sirkulasi penumpang, pemilik, pengguna, serta pengelola bandara.

Dalam penelitian ini terdapat tiga tahapan dalam melakukan analisis :

a. Reduksi dan Kategorisasi Data.

- Mereduksi data yang telah di dapat saat berkunjung langsung ke Bandara Kertajati serta data yang didapat secara literatur.

- Setelah direduksi data dikategorisasikan menurut dua unsur fisik dan non-fisik pada bangunan bandara agar lebih mudah dalam proses display dan analisis.

b. Display data.

Menyajikan data yang berhubungan dengan aspek pragmatik pada bandara, dengan cara menjelaskan secara deskriptif setiap aspek pada objek penelitian yang ada dengan foto dan sketsa tentang bandara terkait yang berhubungan dengan aspek pragmatik pada arsitektural.

c. Penarikan Kesimpulan.

- Mengidentifikasi dan mendeskripsikan bandara studi kasus Bandara Kertajati terpilih terkait konsep pragmatik.

- Menganalisis bagaimana penerapan empat unsur utama arsitektur pragmatik terhadap hasil identifikasi studi kasus Bandara Kertajati

- Mendeskripsikan hasil analisis.

\section{Objek Penelitian}

Bandar Udara Internasional Kertajati adalah bandar udara yang berada di bagian timur laut dari Jawa Barat, Indonesia yang berlokasi di Kabupaten Majalengka, sekitar 68 kilometer di timur Bandung. Sebagai peneliti, saya memilih bandar ini karena bandara yang masih baru dan mudah untuk di akses. Sehingga banyak membantu dalam meneliti lebih lanjut terhadap pendekatan arsitektur pragmatik pada bandara ini. 


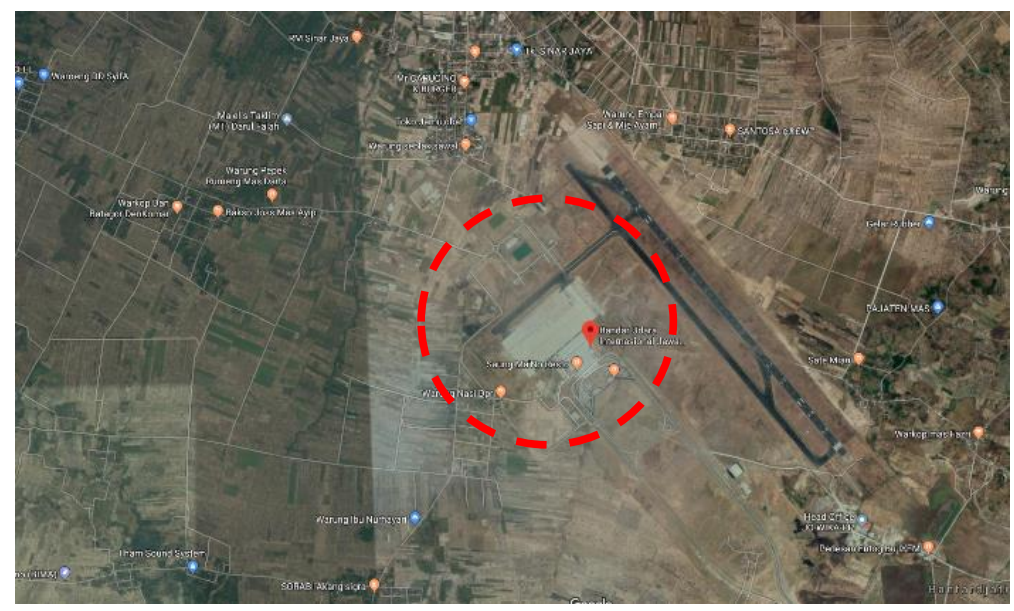

Gambar 2. Peta lokasi bandara kertajati Sumber : google.com/maps, 2019

\section{Hasil dan Pembahasan}

Hasil analisa antara empat unsur utama arsitektur pragmatik terhadap hasil identifikasi studi kasus Bandara Kertajati yaitu;

\section{Desain bangunan lebih mengutamakan fungsi daripada estetika}

Pada unsur pertama, Desain bangunan lebih mengutamakan fungsi daripada estetika. Dalam konsep pragmatik, unsur ini menjadi salah satu poin penting dalam mendesain terutama jika menyangkut tentang terminal sebuah bandara. Pada sebuah terminal bandara, fungsional adalah hal utama yang dilihat oleh para calon penumpang pesawat. Sebagai calon penumpang, jika keamanan dan kenyamanan dapat dirasakan baik, maka ketertarikan bagi para penumpang untuk menggunakan terminal bandara tersebut sebagai salah satu prasarana untuk transportasi akan meningkat meskipun estetika dari bangunan terlihat biasa saja. Hal sebaliknya akan dirasakan bagi calon penumpang pesawat jika bandara memiliki kemanan dan keselamatan yang kurang baik, meskipun estetika bangunan terlihat cukup baik. Hal ini biasanya dapat dilihat dari bentuk massa bangunan dan penempatan entrance serta gatelounge pada sebuah terminal bandara.

1. Massa bangunan

Elemen fisik pertama yang terdapat pada bangunan bandara, yang mengutamakan fungsi daripada estetika terdapat pada massa bangunan yang berbentuk persegi atau persegi panjang. Desain dengan menggunakan bentuk persegi pada massa bangunan, berguna untuk memanfaatkan lahan dengan optimal pada sebuah kawasan bandara. Pada Bandara Kertajati, bentuk terminal bandara terdiri dari dua persegi panjang. Jika ditinjau dari sifat unsur pragmatik, hal ini berfungsi sebagai pemanfaatan lahan agar dapat digunakan untuk bangunan pendukung lain pada bandara.

2. Entrance dan Gatelounge

Elemen fisik selanjutnya, unsur pragmatik yang mengutamakan fungsi daripada estetika, adalah penempatan lokasi antara entrance (pintu masuk) dan gatelounge(tempat ruang tunggu penumpang yang akan naik ke pesawat). Penempatan dua bagian pada terminal bandara yang diterapkan pada ketiga bandara studi berada di dua tempat yang berlawanan. Jika ditinjau pada unsur pragmatik, penempatan ini dilakukan untuk agar posisi gatelounge menjadi ruang yang cukup privat dan terjaga keamanannya. Posisi gatelounge yang berjauhan dari posisi entrance dilakukan dikarenakan fungsi dari 2 gerbang tersebut memiliki kebutuhan 
utama yang berlawanan sehingga, bagi para petugas bandara dapat memperhatikan keamanan dengan baik. Pada bagian gatelounge, kebutuhan utama yang dibutuhkan adalah tempat yang terisolasi dan kemanan yang baik sebelum masuk ke pesawat. Sedangkan pada bagian entrance, pintu masuk harus selalu terlihat kepada setiap pengunjung ataupun calon penumpang pesawat seketika turun dari kendaraan.

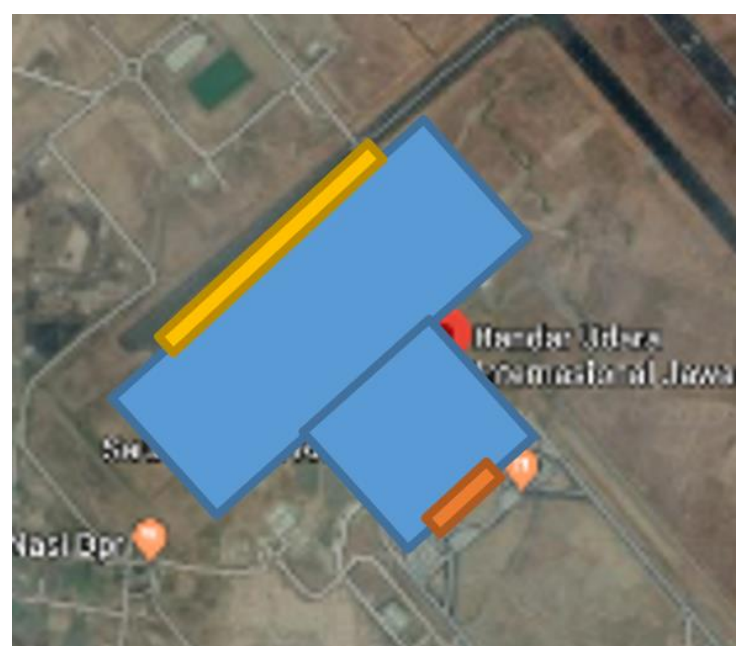

Gambar 3. Massa dan penataan ruang Terminal Kertajati Sumber: Analisa Pribadi, 2019

- Warna biru menunjukan masa bangunan yang berbentuk dua persegi panjang. Desain tersebut menjadi salah satu ciri menggunakan unsur pendekatan pragmatik karena pada umumnya bangunan yang menggunakan bentuk persegi, dan persegi panjang memudahkan dalam mendesain bangunan lain yang harus ada disekitarnya, serta menentukan ruang dalam pada bangunan tersebut agar dapat berguna secara optimal.

- Warna jingga menunjukan lokasi entrance pada bandara yang terdapat pada bagian yang mudah terlihat, dan dekat dengan jalan masuk kendaraan. Dalam unsur pragmatik, penentuan entrance ini menjadi salah satu ciri unsur fungsional pada pendekatan arsitektur pragmatic, karena penentuan tersebut dilakukan agar dapat dicapai dengan mudah bagi para pengunjung terminal.

- Warna kuning menunjukan posisi gatelounge pada jalur keberangkatan, maupun ketibaan. Diposisikan ada di paling jauh dari pintu masuk, dan paling ujung massa bangunan. Dengan mempertimbangkan unsur fungsional pada sebuah bandara, gatelounge ini diposisikan pada area tersebut karena harus mendapat pengamanan extra dan memudahkan bagi para kemanan dalam melihat pergerakan para penumpang, maupun petugas sebelum masuk ke pesawat terbang.

\section{Desain bangunan lebih mengutamakan fungsi daripada estetika}

Elemen pada arsitektur pada sebuah bandara, menjadi faktor pendukung dalam terbentuknya konsep arsitektur pragmatik. Unsur ini mengedepankan penggunaan tanda tanda dan fungsi yang terdapat pada sebuah bandara. Unsur ini dapat dilihat dari beberapa elemen arsitektur, diantaranya adalah bentuk, warna dan tanda yang terdapat pada bagian interior maupun exterior bangunan. Elemen yang menerapkan unsur ini biasanya berguna untuk pengunjung dan calon penumpang pesawat dalam melakukan kegiatan. Kegunaan dari elemen tersebut bias disampaikan secara verbal dan non-verbal yang terdapat di 
bagian elemen bandara. Berikut adalah beberapa elemen yang terdapat di exterior maupun interior bandara dari ketiga studi kasus.

\section{- Pintu Masuk}

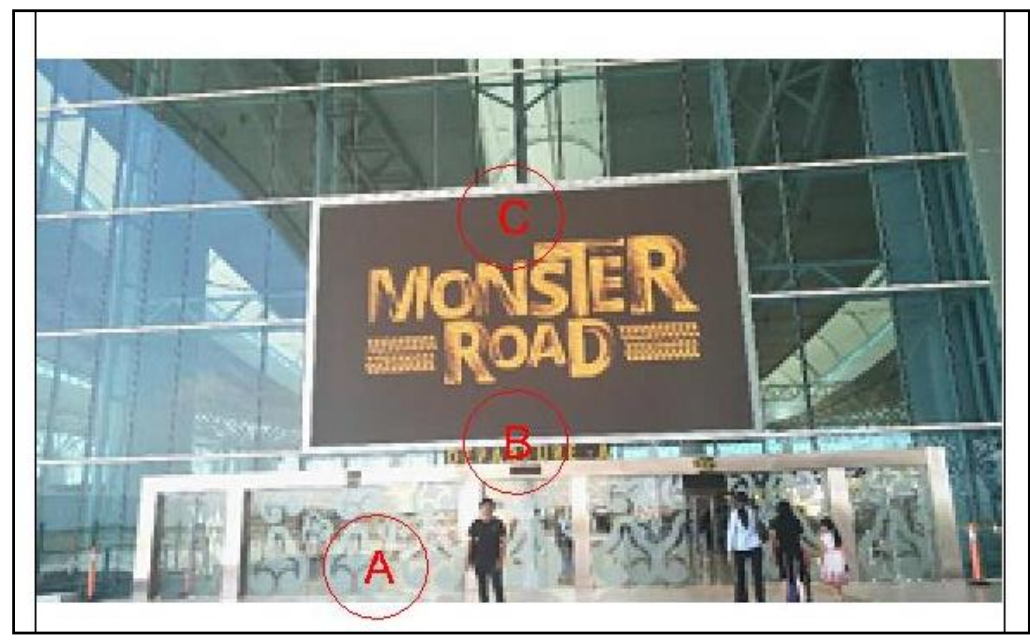

Gambar 4. Pintu Masuk

Sumber: Analisa Pribadi, 2019

Keterangan :

A. Entrance menggunakan elemen arsitektural berupa kaca, dengan frame stainlesssteel. Jika ditinjau dalam unsur pragmatik, hal ini bertujaun untuk memberikan tanda dengan fungsi secara non-verbal sebagai pentunjuk "pintu masuk" bagi para pengguna bandara.

B. Signage yang terdapat pada depan bangunan bertuliskan "DEPARTURE-A" memberikan unsur pragmatik berupa tanda yang menjadi fungsi. Menunjukan bahwa pintu masuk tersebut adalah pintu untuk keberangkatan.

C. Terdapat monitor yang cukup besar. Dalam unsur pragmatik, monitor tersebut berguna untuk mengiklankan para sponsor dari bandara, dan juga sebagai pengumuman apabila terdapat hal darurat untuk diumumkan ke public yang berada di area luar gedung

\section{- Fasad Bangunan}
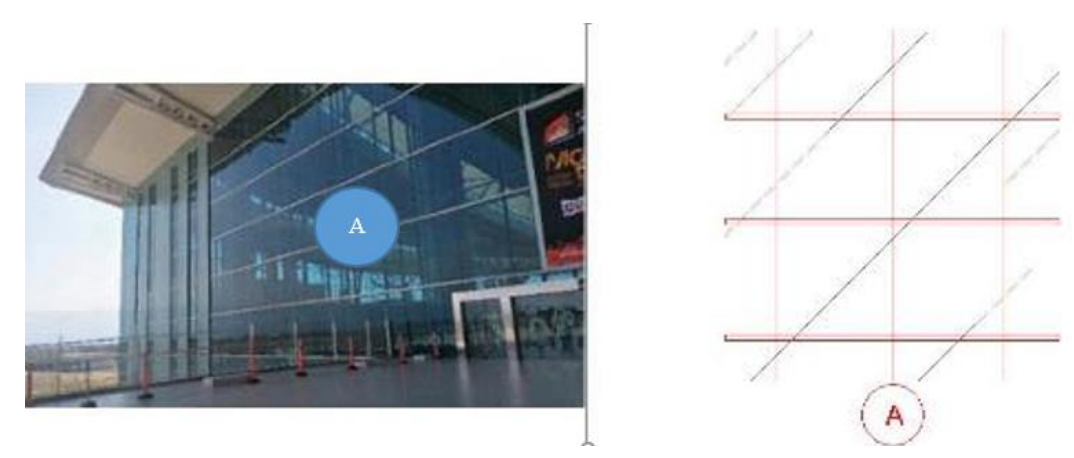

Gambar 5. Fasad Bangunan

Sumber: Analisa Pribadi, 2019

Fasad menggunakan kaca curtain wall. System curtain wall jika ditinjau dari unsur 
pragmatik, maka dinding atau penutup yang berfungsi menjadi filter/pelindung bagian dalam bangunan dari sinar matahari, angin, dan gangguan lainnya dari luar bangunan.

\section{- Check-in counter}

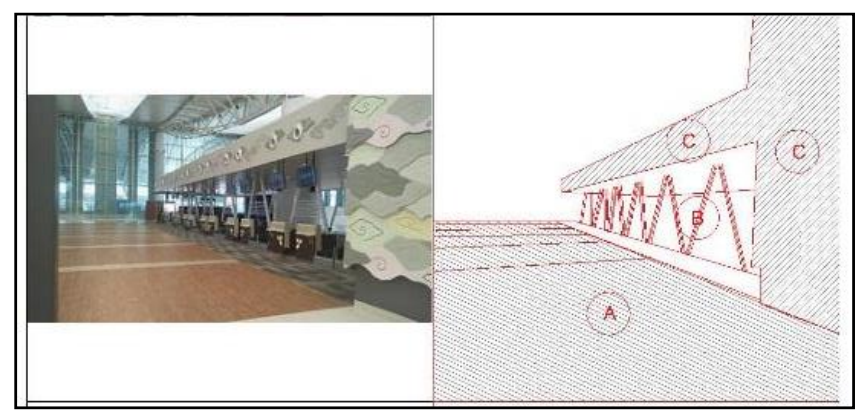

Gambar 6. Check-in Counter Sumber: Analisa Pribadi, 2019

A. Lantai menggunakan lapisan vinyl berwarna coklat dan memiliki motif serat kayu. Jika ditinjau dari unsur pragmatik, maka fungsi dari corak ini menujukan bahwa tempat tersebut menjadi area untuk melakukan kegiatan mengantri pada proses check-in calon penumpang.

B. Pada area tersebut terdapat tiang-tiang yang berada di dekat konter dengan lantai karpet bermotif kotak. Dinilai dari unsur pragmatik, hal ini berfungsi sebagai tanda non-verbal bagi para calon penumpang pesawat yang antri untuk melakukan checkin bahwa, area tersebut bukanlah area publik, dan hanya petugas berwenang dari bandara yang boleh melewati area tersebut.

C. Penggunaan material yang bermotif pada dinding $\neg$ check-in counter dan ruang disebelahnya, berfungsi sebagai fokus utama bagi para calon penumpang agar melihat check-in counter mengikuti alur proses keberangkatan.

\section{- Toilet dan Ruang Penunjang}

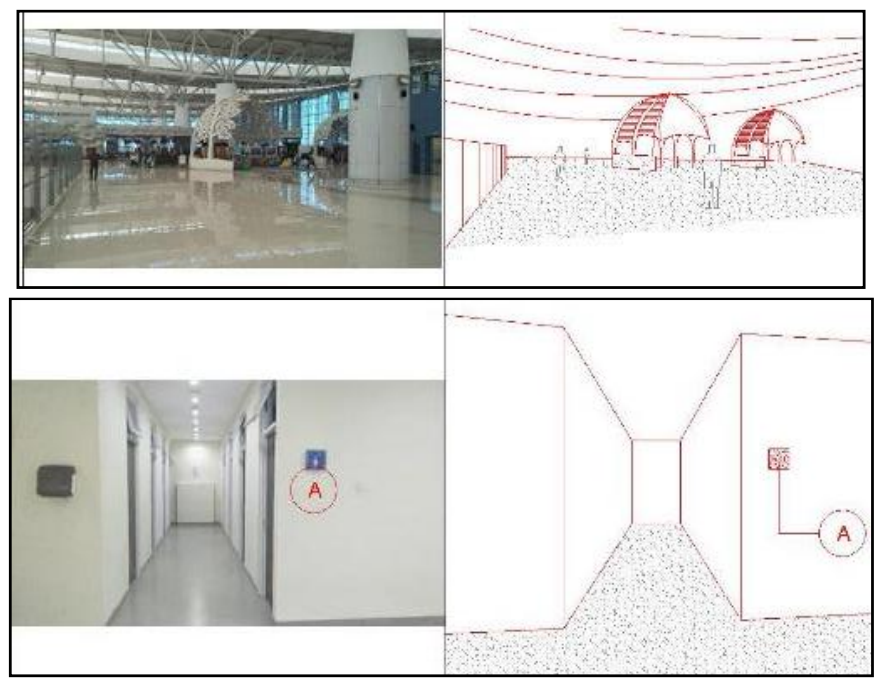

Gambar 7. Toilet Kertajati

Sumber: Analisa Pribadi, 2019 
Keterangan:

A. Signange toilet yang memiliki unsur pragmatik sebagai penujuk tempat bahwa terdapat toilet yang ada di Lorong tersebut. Penggunaan warna pada tanda toilet tersebut terlihat kontras dengan warna dinding. Jika ditinjau dari unsur pragmatik, hal ini agar orang sekitar dapat melihat dengan mudah.

B. Terdapat desain elemen interior yang membentuk ruang secara tidak langsung, menggunakan warna putih dan bentuk dahan serta daun pohon pada bagian atap ruang tersebut. Ruang tersebut digunakan untuk butik, perpustakaan, dan sekedar tempat istirahat. Pada unsur pragmatik, hal ini berfungsi sebagai hiburan bagi para pengantar dan calon penumpang, agar menunggu jadwal penerbangan sambil melakukan aktifitas lain pada ruang tersebut

\section{- Signage pada beberapa ruangan di terminal bandara}

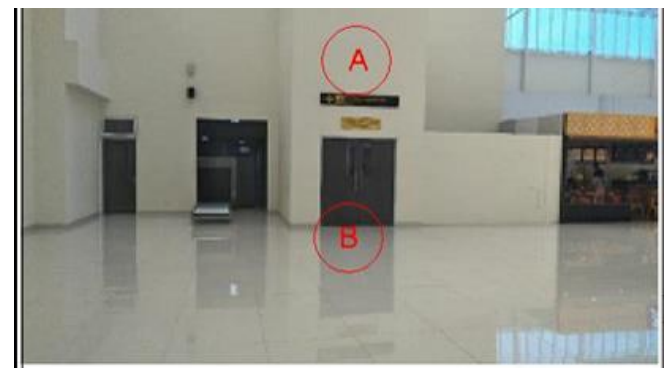

Gambar 8. Signage terminal Bandara Sumber: Analisa Pribadi, 2019

Keterangan :

A. Signange pada paling atas dari pintu tersebut bertuliskan "jalur keberangkatan", dan pada bagian bawahnya terdapat signage lain yang bertuliskan "kantor kesehatan pelabuhan". Selain itu ada juga signage yang berdiri di atas lantai. Ketiga signage tersebut berfungsi untuk penunjuk arah dan nama dari ruang tersebut. Jika dilihat dari unsur pragmatik, bandara ini menggunakan warna dasar hitam dan kuning agar terlihat kontras dengan warna dinding dan lantai sehingga dapat dilihat dengan mudah terlihat oleh orang sekitar.

B. Penggunaan warna pintu yang gelap juga menunjukan warna kontras agar mudah terlihat.

\section{- Pintu Darurat}

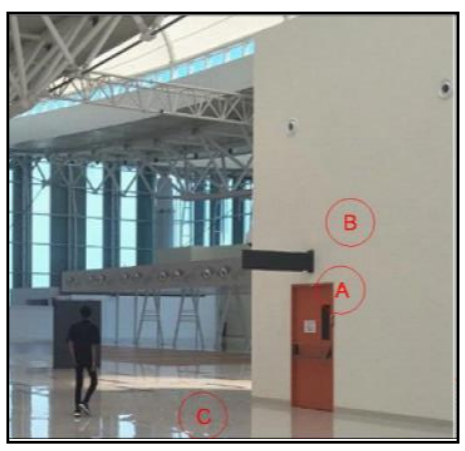

Gambar 9. Pintu darurat Sumber: Analisa Pribadi, 2019 
Keterangan :

i. Terdapat pintu darurat yang diletakan pada posisi yang mudah terlihat dari sirkulasi bangunan. Warna yang digunakan cukup kontras yaitu wara jingga hampir kemerahan. Posisi dan pewarnaan pintu darurat menggunakan unsur pragmatik dalam hal fungsi, karena elemen tersebut terlihat dengan mudah oleh orang yang ada di sekitar pintu tersebut.

ii. Dinding yang berawarna putih membuat kontras dari pintu darurat.

iii. Lantai marmer berwarna yang juga membuat kontras dari warna pintu darurat

\section{- Desain Skylight}
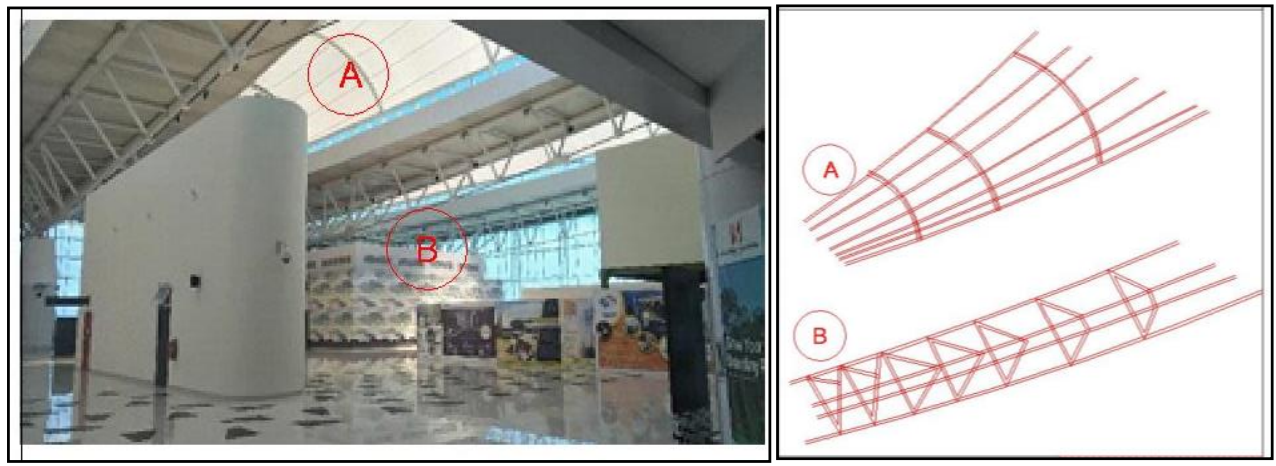

Gambar 10. Skylight

Sumber : Dokumen Pribadi, 2019

Keterangan;

A. Rangka atap yang menggunakan baja seamless (pipa) yang melengkung dengan perpaduan warna krem dan putih. Dalam unsur pragmatik, hal ini berfungsi agar atap ruang tersebut terkena langsung oleh sinar matahari, dan memberikan kesan lebih luas. Hal ini didukung oleh sifat warna putih yang menangkap cahaya lebih banyak daripada warna lainnya.

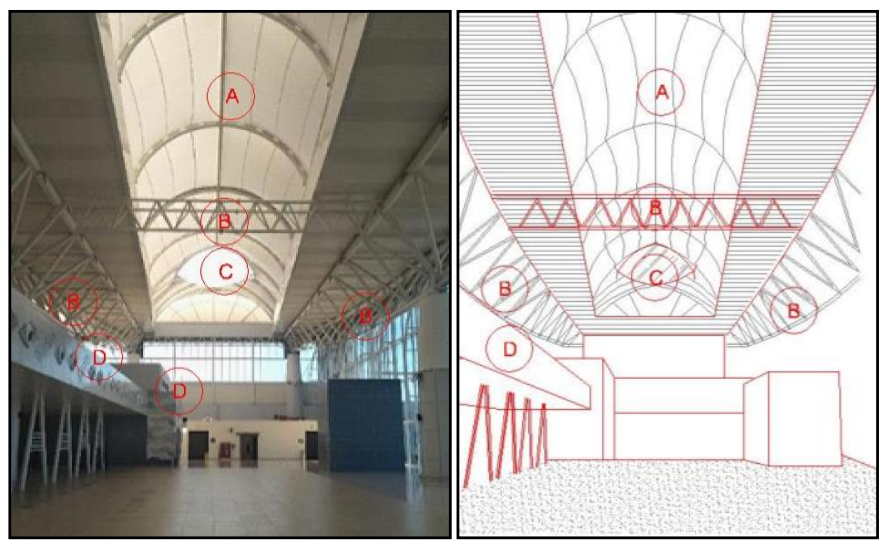

Gambar 11. Atap dan Skylight

Sumber : Dokumen Pribadi, 2019

B. Desain atap pada bangunan ini banyak di ekspos secara langsung tanpa di cover dan hanya di finnish dengan warna cat putih dan krem. Rangka atap seamless (pipa) dibentuk segitiga segitiga dan menjadi penopang dari finising atap yang diatasnya. Jika ditinjau dari unsur pragmatik rangka atap ekspos ini memberikan tanda ke 
kokohan dan memberikan kesan kenyamanan jika berada di bawahnya. Hal ini berguna agar orang yang berkegiatan di area tersebut menjadi tidak merasa terlalu bosan.

C. Skylight yang tedapat di tengah atap tersebut berbahan dari tempered glass yang melengkung berbentuk serperti mata. Dalam unsur pragmatik, bagian ini menjadi kunci utama dalam penerangan cahaya alami dalam ruangan. Perpaduan cahaya dari skylight dan pantulan cahaya dari warna putih yang terdapat di bagian sekitarnya, memberikan pencahayaan yang cukup baik.

D. Jika dilihat dari unsur pragmatik, bagian check-in counter ini, paling mendapatkan dukungan unsur pragmatik pencahayaan dari point elemen $A, B$ dan $C$.

\section{Pengaturan sirkulasi pengunjung dan pengelola, pada sebuah terminal bandara agar sesuai dengan fungsinya}

Sirkulasi yang diatur pada bandara ketiga studi kasus, utamanya ditentukan oleh bentuk jalur, dan penggunaan elemen arsitektural yang telah di bahas pada sub-bab sebelumnya. Hal tersebut sangat mempengaruhi baik dan tidaknya pihak bandara dalam mengatur sirkulasi tersebut, terutama jika kita melihat fungsi bangunan bandara yang sangat memperhatikan unsur keamanan dan kenyamanannya.

Pada bandara Kertajati, alur sirkulasi dibagi menjadi tiga jenis, yang dilakukan pada 3 lantai yang berbeda. Alur sirkulasi tersebut dibagi menjadi alur keberangkatan, alur kedatangan, dan juga alur untuk pengunjung bandara.

1. Alur keberangkatan

Alur keberangkatan berada pada lantai 3, dimulai dari entrance hingga menuju ke security check point lalu dilanjutkan ke lantai dua untuk menuju ke gate lounge atau ruang tunggu pesawat. Jika dilihat dari unsur pragmatik, pemisahan ini dilakukan agar dapat terlihat dengan jelas bahwa lantai tiga dan dua hanya diperuntukan untuk penumpang yang ingin naik pesawat pada alur keberangkatan bandara kertajati.

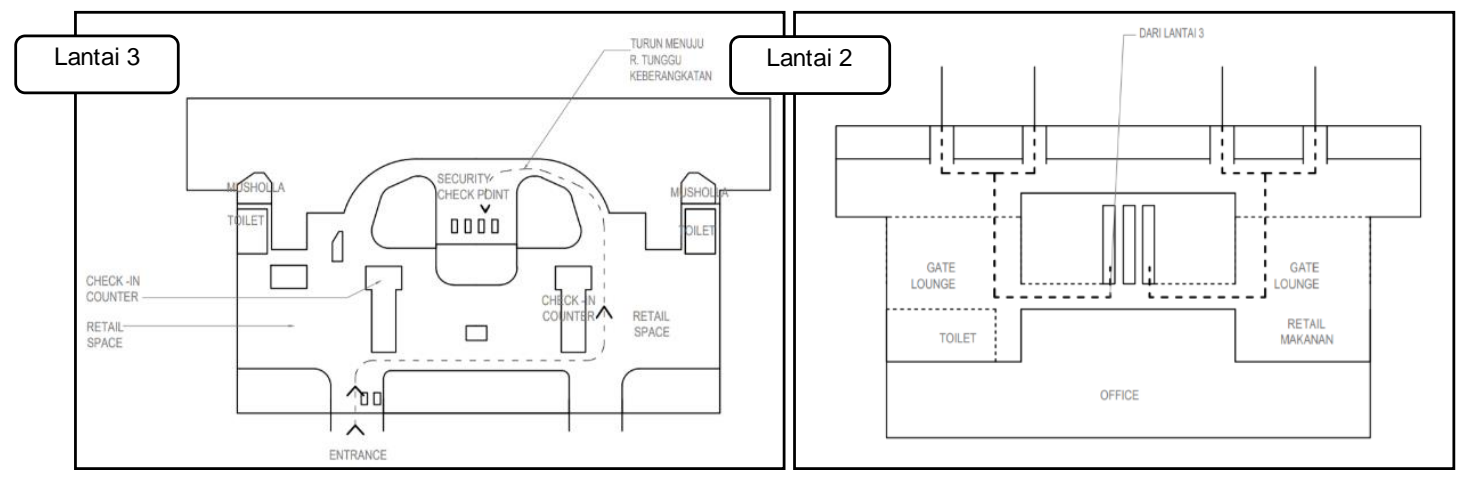

Gambar 12. Lt. 3 dan Lt. 2 Keberangkatan Sumber : Dokumen Pribadi, 2019

\section{Alur Ketibaan}

Jalur kedatangan dipusatkan pada lantai pertama bangunan terminal. Jika ditinjau dari unsur pragmatik, hal ini dilakukan agar tidak mengganggu proses dari alur keberangkatan yang berada di lantai 2 dan 3. Selain itu hal ini juga memberikan kemudahan bagi para pihak keamanan bandara dalam pengecekan kemanan ketika penumpang tiba di bandara tersebut. Pada bandara ini alur ketibaan juga dipisahkan sesuai dengan pesawat yang menurunkan penumpang di bandara tersebut, jika 
mereka pada alur ketibaan domestik, maka pemeriksaan hanya dilakukan sekali, namun untuk alur ketibaan internasional, maka pemeriksaan harus dilakukan sebanyak dua kali dan ditambah dengan pemeriksaan surat menyurat internasional.

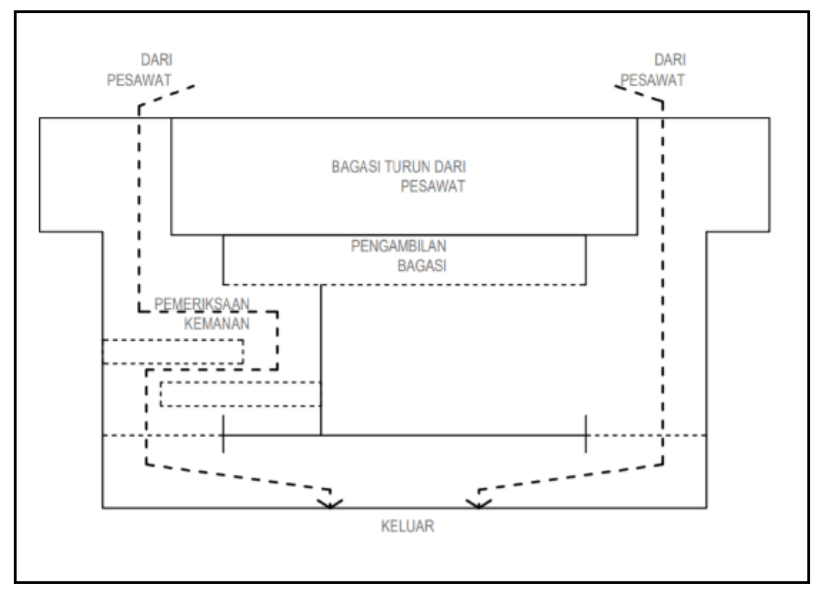

Gambar 13. Lt. 1 Ketibaan

Sumber : Dokumen Pribadi, 2019

\section{Alur Pengunjung Bandara}

Pengunjung bandara memiliki area yang dapat tersendiri pada bandara ini. Area tersebut diisi oleh retail-retail yang berada sebelum melewati area pengecekan keberangkatan dan sesudah melewati pengecekan alur ketibaan. Hal ini cukup sejalan dengan unsur pragmatik pada bandara ini. Pengaturan alur pengunjung pada bandara ini mendapatkan tempat yang sesuai dan cukup baik, namun juga masih dapat terjaga keamanannya dengan baik.

\section{Kesimpulan}

Penerapan konsep pragmatik pada Bandara Kertajati dapat dilakukan dengan cara menerapkan 4 (empat) unsur yang terdapat pada objek fisik dan non-fisik. Penerapan unsur tersebut dengan cara;

1. Desain yang dibuat lebih mengutamakan fungsi daripada estetika.

2. Elemen pada arsitektur yang berfungsi sebagai tanda-tanda yang memiliki arti dan fungsi bagi pemakainya. Hal ini dapat ditinjau melalui bentuk, warna, dan penggunaan tanda pada bangunan bandara.

3. Menerapkan sirkulasi pada jalur keberangkatan dan ketibaan pada sebuah bandara, dengan memperhatikan aspek keamanan dan kenyamanan bagi seluruh pengguna bandara.

4. Memperhatikan segala aspek non-fisik yang mempengaruhi jalannya kegiatan seluruh pengguna bandara.

Elemen arsitektur pada sebuah bandara, yang berkaitan dengan konsep arstektur pragmatik adalah elemen-elemen bangunan yang mempengaruhi aspek fungsional. Elemen-elemen tersebut berperan sebagai informasi dari penujuk arah dan area apa saja yang dapat digunakan serta tingkat kemanan dan kenyamanan untuk para pengguna bandara yang disampaikan melalui desain bangunan secara verbal (signage) dan nonverbal. Elemen arsitektur bandara yang menerapkan unsur pragmatik diantaranya adalah;

1. Pintu masuk bandara (entrance) 
2. Fasad bangunan

3. Check-in counter

4. Toilet dan Ruang Hiburan

5. Sigange pada beberapa ruangan di terminal bandara.

6. Desain pintu darurat

7. Desain langit-langit

Hasil dari analisis studi kasus unsur pertama pada pragmatik yang berbunyi "Desain yang dibuat lebih mengutamakan fungsi daripada estetika" yang diterapkan pada ketiga studi kasus, terdapat estetika yang cukup baik, meskipun tidak melupakan unsur pragmatik yang terdapat di dalamnya.

\section{Ucapan Terimakasih}

Ucapan terimakasih penulis sampaikan kepada beberapa pihak yang telah mendukung penyelesaian jurnal ini:

1. Bapak Wafirul Aqli, ST., M.SC., selaku Ketua Jurusan Arsitektur.

2. Ibu Anisa, ST., MT., selaku Koordinator Seminar Tugas Akhir dan pembimbing akademik.

3. Bapak Lutfi Prayogi, S.Ars., M.Urb.Plan., selaku pembimbing Seminar Tugas Akhir.

4. Bapak dan Ibu Dosen Jurusan Arsitektur Universitas Muhammadiyah Jakarta, yang tidak bisa saya sebutkan satu persatu, namun tidak mengurangi rasa hormat saya.

5. Orang tua Saya yang telah memberikan doa, motivasi, nasihat dan semangat selama menempuh program Sarjana di Arsitektur FT-UMJ.

6. Seluruh pihak yang telah membantu, yang tidak dapat disebutkan satu persatu dalam penyusunan jurnal ini, Saya ucapkan terima kasih banyak.

Semoga peneltian ini dapat bermanfaat bagi perkembangan disiplin ilmu Arsitektur. Terimakasih.

\section{Daftar Pustaka}

Chairil, Amiuza, \& Ridjal, A. M. (2015). Semantik Arsitektur Pada Pasar Seni Kabupaten Sidoarjo. Arsitektur Student Journal, 1-7.

Fista, G. (2020, January 9). 20 Bandara Tersibuk di Dunia 2019, Soekarno-Hatta Jadi Salah Satunya. Retrieved from Kumparan.Com: https://kumparan.com/kumparantravel/20-bandara-tersibuk-di-dunia-2019soekarno-hatta-jadi-salah-satunya-1r8mJf6u5Jl/full

Imaji. (2019). Desain Bandara Nusantara Alor. Jakarta: PT.Imaji Media Pustaka.

M. Pinem. (2016). Sejarah, Bentuk dan Makna Arsitektur Gereja GPIB Bethel Bandung. Jurnal Lektur Keagamaan.

Manaroinsong, K. E. (2017). Penerapan Analogi Llinguistik pada Arsitektur dengan Menggunakan Prinsip Seni Ekspresionis. Media Matrasain, https://ejournal.unsrat.ac.id/index.php/imm/article/view/18470/18003.

Sari, I. R. (2014). Analisis Pragmatik Pelanggaran Tindak Tutur Guru Di Sma Lentera. online jurnal UNIJA, 1-14. https://online-journal.unja.ac.id/pena/article/view/2328 
Subagyo, P. A. (2010). Pragmatik Kritis : Paduan Pragmatik dengan Analisis Wacana Kritis. Linguistik Indonesia, https://www. linguistik-indonesia.org.

Sutrisno. (2020, Januari 10). Ruang Tunggu Lebih Jauh, Akses Jalan Jadi Keluhan, Tapi Terminal Baru Tetap Bikin Warga Penasaran. Retrieved from Pro Kalimantan Selatan: https://kalsel.prokal.co/read/news/28811-ruang-tunggu-lebih-jauh-aksesjalan-jadi-keluhan-tapi-terminal-baru-tetap-bikin-warga-penasaran

T, C., Dariwu, \& Rengkung, J. (2012). Kajian Semiotoka Dalam Arsitektur Tradisonal Minahasa. Media neliti, 1-6.

Yunianti, E. (2015). Estetika Unsur-Unsur Arsitektur Bangunan Masjid Agung Surakarta. Journal Unnes, 3-4. 